\title{
GEOLOGICAL AND GEOTECHNICAL BEHAVIOUR OF EVINOS DAM FOLLOWING THE IMPOUNDMENT
}

\author{
Angelopoulos A. ${ }^{1}$, Soulis V.J ${ }^{2}$, Malandraki V. ${ }^{\mathbf{3}}$ \\ ${ }^{1}$ Geologist, Geophysist, Division of Raw Water Intake, Athens Water Supply and Sewage Company S.A \\ (E.YD.A.P S.A), Galatsiou 16, Athens, Greece, angelopoulos@eydap.gr \\ ${ }^{2}$ Dr Civil Engineer, Division of Raw Water Intake, Athens Water Supply and Sewage Company S.A \\ (E.YD.A.P S.A), Galatsiou 16, Athens, Greece, vsoulis@eydap.gr \\ ${ }^{3}$ Dr Civil Engineer, Division of Raw Water Intake, Athens Water Supply and Sewage Company S.A \\ (E.YD.A.P S.A), Galatsiou 16, Athens, Greece, malavas@eydap.gr
}

\begin{abstract}
The Evinos dam built between 1993 and 1997. The period of construction followed a period of rest until 2001. The impoundment of the Evinos Dam and the subsequent $3^{\text {rd }}$ operational period took place between 2001 and 2005. The $4^{\text {th }}$ period of operation commenced in February 2005 and concerns the period of regular operation of Dam Evinos after completion. During this period, sufficient data have been gathered for the evaluation of the geotechnical behaviour of both Evinos Dam itself and the stabilization works on the two landslides that occurred (Landslide of the left abutment '93, Landslide of Ag.Demetrios-Arahova country road). Specialized personnel of the Department of the Evinos Dam of the Athens Water Supply and Sewage Company S.A are responsible for the in-situ collection of instrumental readings. On the other hand specialized personnel of the Division of Raw Water Intake of Athens Water Supply and Sewage Company S.A are assigned to evaluate the dam's behaviour. The infiltration of water within the Dam's core is continuously monitored together with the horizontal movement and settlement upstream and downstream the dam's body through a considerable number of vibrating wire piezometers, earth pressure cells, extensiometers, inclinometers and surface monumental stations. The behaviour of the stabilization interventions in the landslide area's are evaluated through measurement of topographic monuments, open piezometers and drainage measurements. The evaluation of the instrumental measurerements confirms the expected behavior of the dam and the satisfactory performance of the stabilization interventions in the landslide area's.
\end{abstract}

Key words: Evinos Dam, evaluation, geotechnical behaviour, landslides, piezometers, settlement, movement

\section{Introduction}

The Evinos Project, Dam and tunnel of Evinos - Mornos belongs to the second phase of the water supply scheme for the city of Athens and its wider area. The geological formations of the reservoir and the area of the dam foundation consists of flysh a highly deformed complex of sandstones ,sisltstones and mudstones Fig.1. The intersection of the dam comprises a central core with material from the clay phase of the flysch, filter transition zones and support bodies of the river's sandstone. The lower parts consist of rocky materials from excavations. Dounias \& Papageorgiou, 2001 are de- 


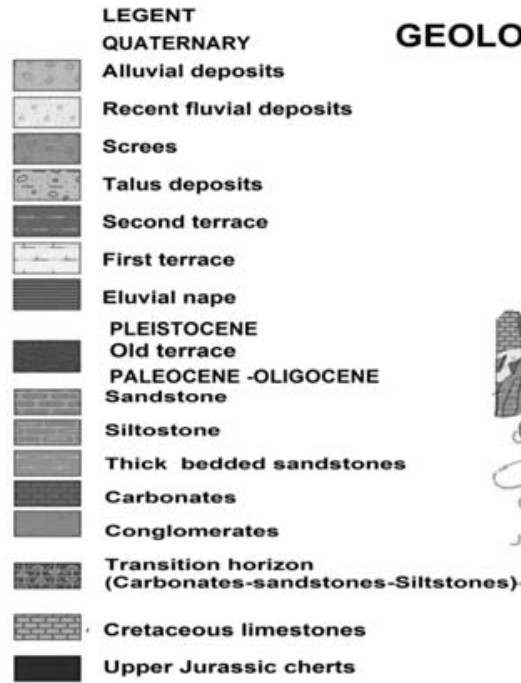

Fig. 1: Geological map of Evinos dam site.

scribing the construction materials and the impermeable clay core made from flysch siltstones of Evinos Dam. The reasons that an earth fill dam with impermeable clay core was initially selected for the design of Evinos Dam were the high fractured geological formation of the area, the high seismic demands and the satisfactory performance of similar projects in analogous geological conditions (e.g. Kremasta, Kastraki Pournari, Mornos, Dounias \& Papageorgiou, 2001). During the construction of Evinos Dam two landslides occurred. The first initiated in the Agios Demetrios-Arahova Country Road in the left abutment of the dam ,while the second one occurred in August 1993, in the same abutment, just before the spillway entrance. The behaviour of the Dam's core is continuously monitored utilizing a number of instruments (vibrating wire piezometers, earth pressure cells, extensiometers, inclinometers, surface monumental stations). These instruments are placed in three sections IV, IX, XI, within the dam's body Fig 6. The evolution of the two landslides is also monitored (Angelopoulos et al., 2007, 2008).

\section{Evinos dam}

\subsection{Piezometers}

A large number of vibrating wire piezometers were installed in the shoulders and the core of the dam. The pore water pressure development differs through the dam due to the partial saturation and the low permeability values of the core. Piezometers Pz11-19 are placed in Section VI of the Evinos dam. In fig. 2 piezometers Pz11, Pz12 and Pz17 initially show no response in the changes of the reservoir level. In March 2006 the reservoir has overflowed. This period lasted for 3 months initiating the response of piezometers to the changes of the reservoir level. Piezometer Pz11 is more sensible to changes of reservoir level. This behaviour indicates that a flow net has been gradually started to establish in the core even for higher values of the reservoir level. Piezometers Pz14 and $\mathrm{Pz} 19$ which are installed in the filter zone(free drainage material), showed a constant piezometric level through time. In fig. 3 the changes in the piezometric level of piezometers Pz31-33-34 are 
Evolution of piezometric level with time in Section VI

$\mathrm{Pz}$ in El. 448 down to $425 \mathrm{~m}$

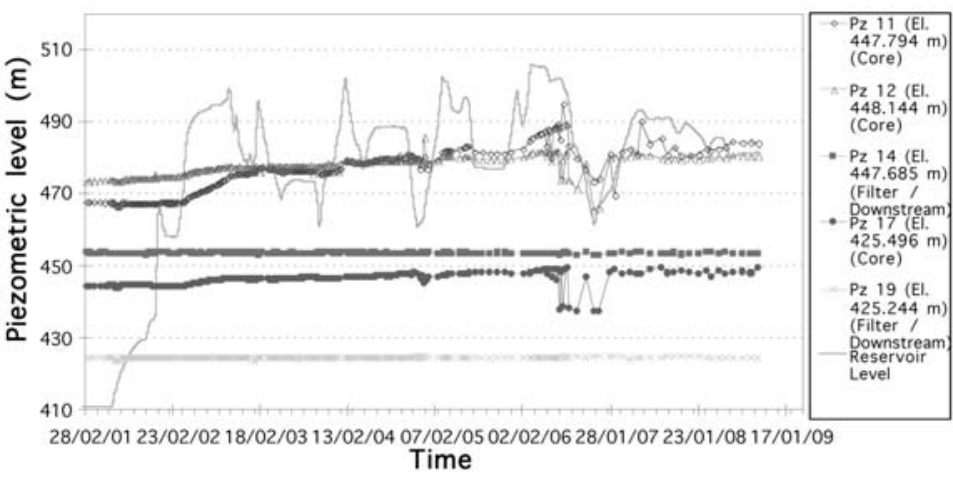

Fig. 2: Evolution of piezometric level in piezometers located in Section VI of the dam.

Evolution of piezometric level with time in Section IX-

$\mathrm{Pz}$ in $\mathrm{El} .447$ down to $423 \mathrm{~m}$

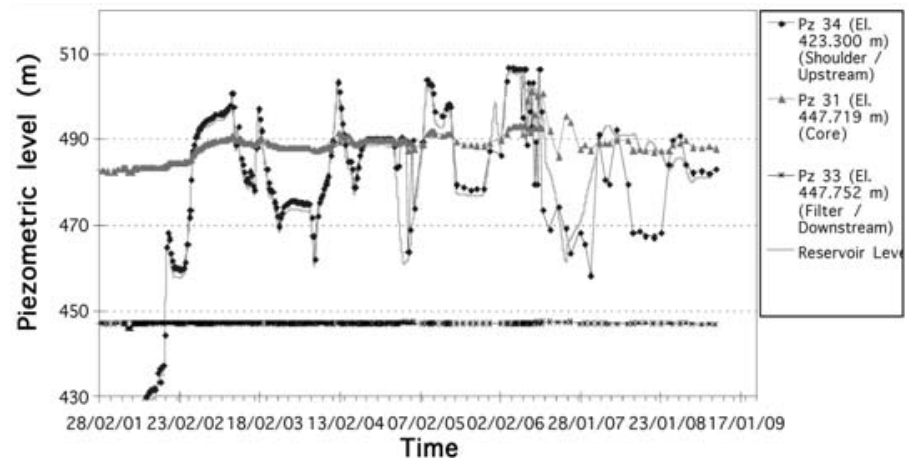

Fig. 3: Evolution of piezometric level in piezometers located in Section IX of the dam.

shown. These piezometers are placed upstream, downstream and at the core of the dam's body in section IX. Piezometer Pz34 which is installed upstream generally follows the fluctuation of the reservoir level. However, there was a period of drop of the reservoir level in the end of 2007 that Piezometer Pz34 didn't follow. Piezometer Pz 33 is placed in the filter zone downstream the dam's body. It shows no changes in its piezometric level as it is a free drained material. The study of the pore pressure development generally confirms the successful response of dam's core.

Piezometers are also placed in the foundation of the dam to inspect both the piezometric level in the foundation and the effectiveness of the grout curtain. In fig. 4 changes of the piezometric level measured in piezometers placed along Section VI can be depicted. Piezometers Pzf 11, Pzf 12, Pzf 26 show constant piezometric level through time. Piezometers installed upstream Pzf9, Pzf 10 show roughly constant piezometric level (about +420 ), which is influenced by the level of rainfall. Hydraulic piezometers are also installed through the grout curtain tunnel.Phc 2 follows the changes observed in the reservoir level. Phc 3 is less sensible to changes of the reservoir level. The response of piezometers placed in the foundation of Evinos Dam show little infiltration from the reservoir. 
Evolution of piezometric level with time in Section VI-Pzf9 up to 10, 11, 12,26 and $\mathrm{Ph} 2, \mathrm{Ph} 3$

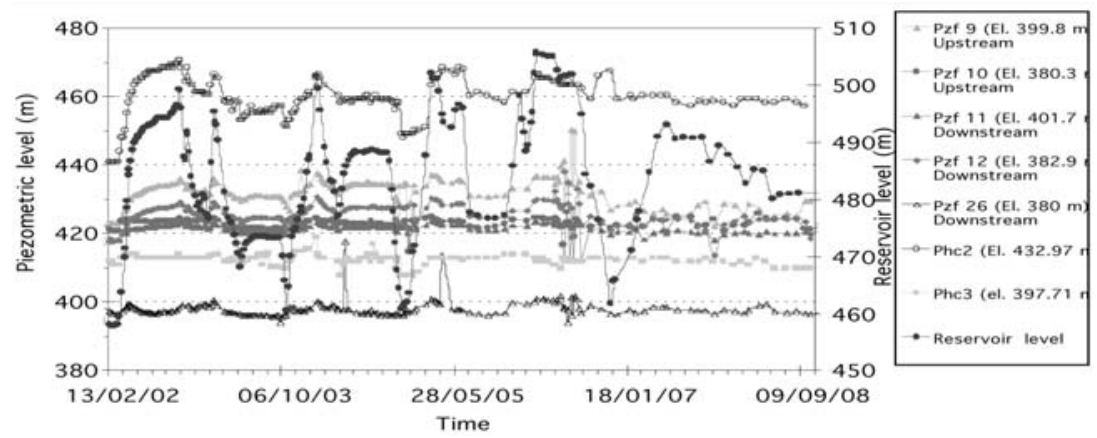

Fig. 4: Evolution of piezometric level in piezometers located in the foundation of the dam.

Evolution of movement and settlement at Dam's Crest Group of Stations S68-S72

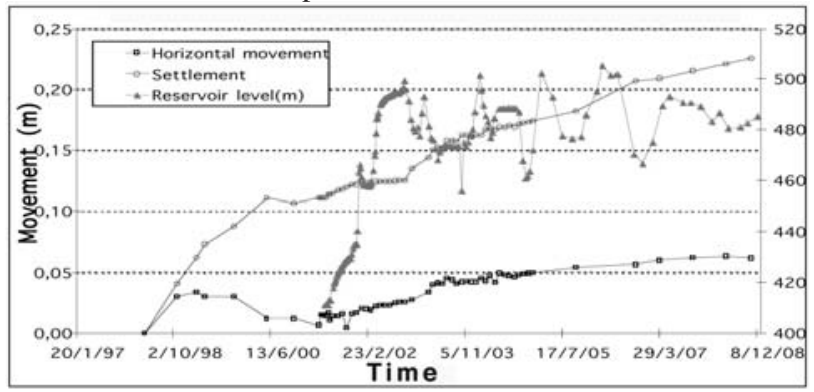

Fig. 5: Cumulative mean displacements and settlement in the dam's Crest.

\subsection{Settlement and horizontal movement}

Additionally the evaluation of the stability of Evinos Dam is carried out through the systematic measurement of horizontal and vertical movement of the dam's crest. In the dam's crest a number of surface monumental stations have been positioned upstream and downstream the dam's longitudinal axis (S24 -S33 upstream, S64-S73 upstream, Dounias, 2006). In fig. 5, the evolution of horizontal and vertical movements in respect with time are depicted for the same group of stations.The horizontal movement of the dam's crest is gradually increasing through time, although its magnitude is negligible. The settlement of the dam is increased following the impoundment of the reservoir. A slight increase of settlement rate is recorded even in the 4th period of operation in the dam's crest (February 2005-November 2008, Angelopoulos et.al., 2007,2008). During this period of operation the maximum settlement recorded is of the order of $5.2 \mathrm{~cm}$. The total settlement of the dam's crest is of the order of $22.6 \mathrm{~cm}$ and is regarded as safe. In fig. 6 the cumulative horizontal displacements Dx and settlement Dv for the group of stations S68-S72 in the dam's crest is presented. In the same figure the cumulative displacements Dx and settlement Dv for the group of stations $\mathrm{B \Theta} 3-\mathrm{B} \Theta 7$ in the area of the landslide of the left abutment ' 93 is also presented. The small vector denotes the displacements values and settlement in the date of impoundment (11/2001), the large vector denotes the displacement and settlement in the end of 2008 (12/2008). 


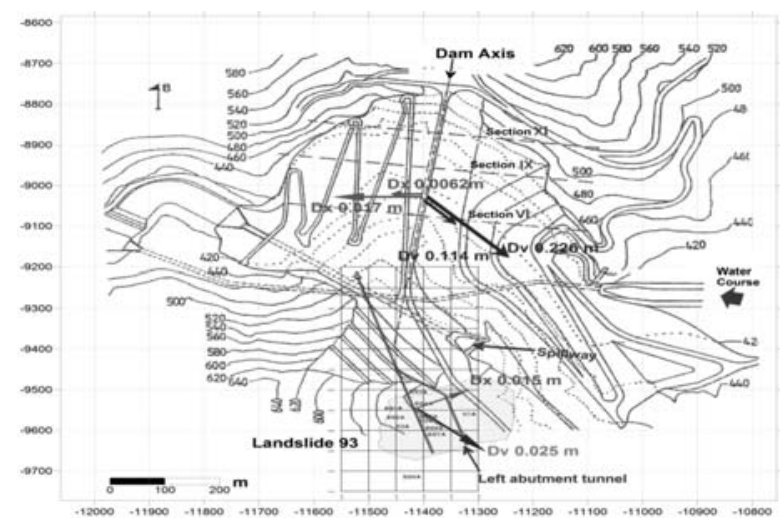

Fig. 6: Cumulative displacements Dx and settlement Dv for the group of stations S68-S72 in the dam's

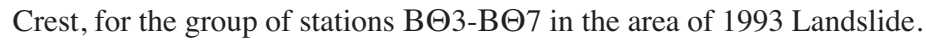

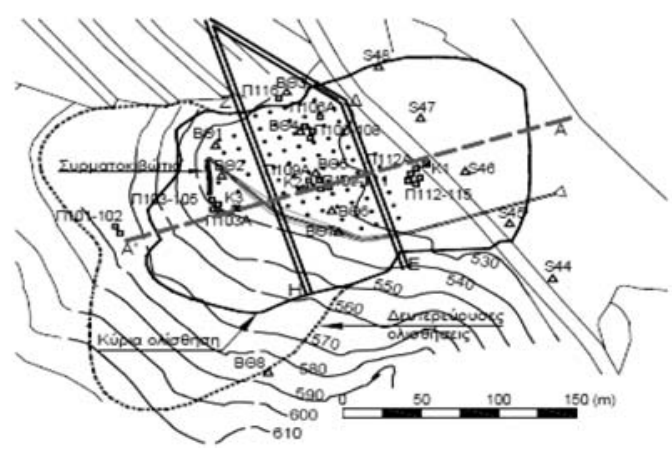

Fig. 7: Drainage tunnels and piezometers located in the area of the Landslide of the left abutment ' 93.

\section{Landslide of the left abutment' 93}

In August 1993 a landslide occurred in the left abutment of Agios Demetrios just before the entrance of the spillway. The stabilization works included the construction of a drainage tunnels together with the construction of wells. The behaviour of the stabilization measurements are monitored by in-situ measurements in a) piezometers, b)inclinometric - settlement columns, c) surface monumental stations, d) devices measuring the flow in the exit of the drainage tunnels. In fig. 7, the stabilization measurements are depicted together with the positions of piezometers and surface monumental stations (Dounias \& Dede, 2006).

\section{Piezometers}

The piezometric levels are continuously monitored after the completion of stabilization works. Piezometers are placed in different depths within the landslide's body. The deepest one is placed inside the substratum. In figs. 8,9 the fluctuation of peizometric level in respect with time can be depicted. In the same figures the fluctuation of rainfall and the fluctuation of the reservoir's water level are recorded during the monitoring period. The stabilization works succeeded in reducing the piezometric level of deep piezometers that exhibit an immediate response in respect to the rainfall but they also exhibit an immediate pore pressure decrease. The piezometers located in depth up to 15.00m (i.e П105 depth 4.25m, П108 depth 12.30m, П111 depth 12.20m, П115 depth $11.40 \mathrm{~m}$ ) ex- 


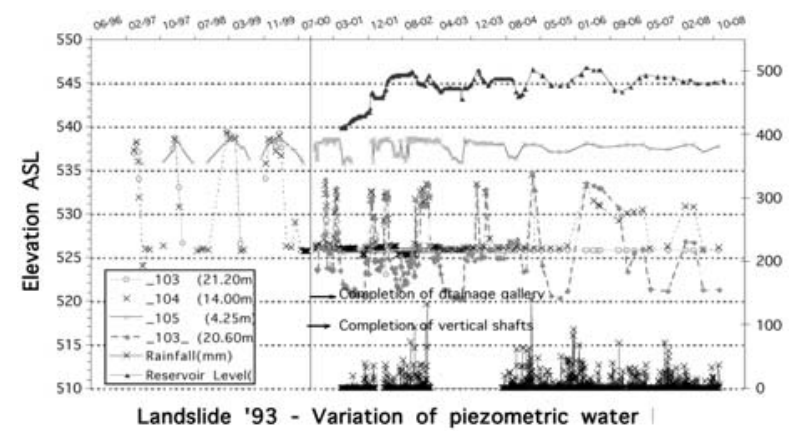

Fig. 8: Piezometric measurements of group П103-П105

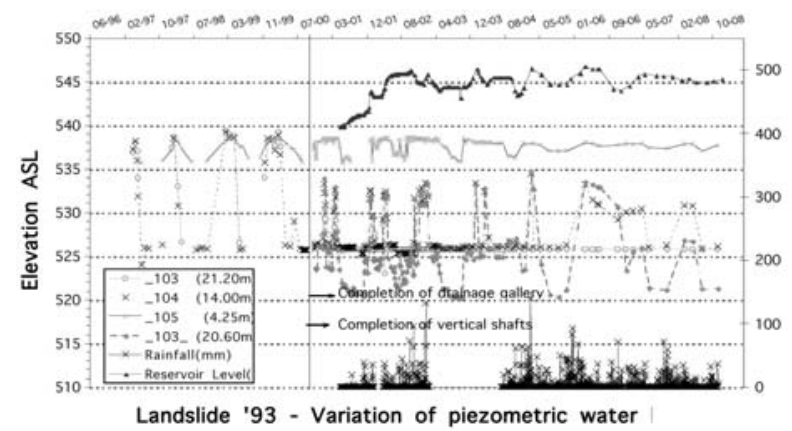

Fig. 9: Piezometric measurements of group П112-П115.

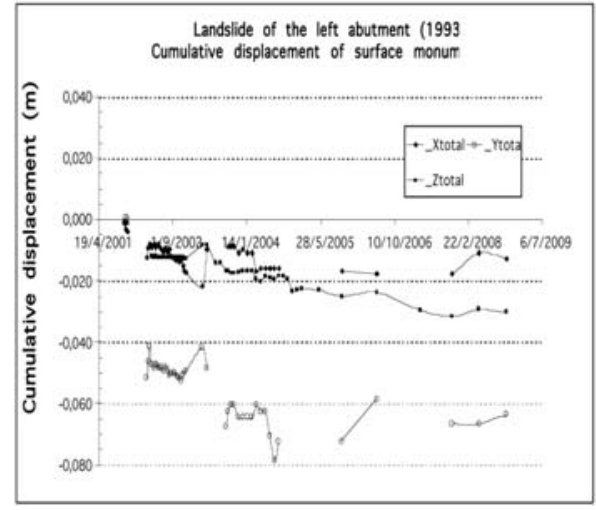

Fig. 10: Measurement of displacements in station K1 nearby piezometers $\Pi 112-115$.

cept the piezometer $\Pi 104$ (depth $14.00 \mathrm{~m}$ ) show reduced fluctuation of piezomentic level after the completion of drainage tunnels. Piezometers placed in deeper levels (i.e $\Pi 106$ depth 30.00m, П109 depth $32.80 \mathrm{~m}$ ) do not exhibit any fluctuation of their piezometric level and they are considered as dry. In spring 2006 the dam has overflowed for a total period of three months. Piezometers П103A and $\Pi 104$ maintained their high piezometric level besides the substantial drop in the reservoir's level.

\subsection{Settlement and horizontal movement}

The surface monumental stations $(\mathrm{K} 1, \mathrm{~K} 2, \mathrm{~K} 3$ and $\mathrm{B} \Theta 1-\mathrm{B} \Theta 8)$ have been placed inside the area of the landslide aiming to capture possible excessive settlement and horizontal movement (Figs 10, 11). 


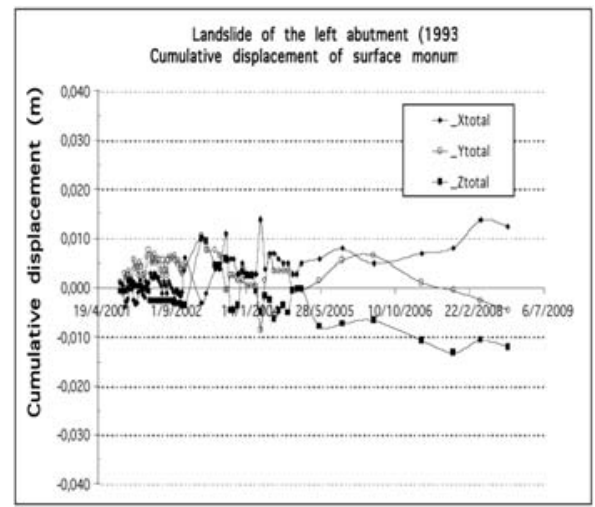

Fig. 11: Measurement of displacements in station K2 nearby piezometers П109-111.

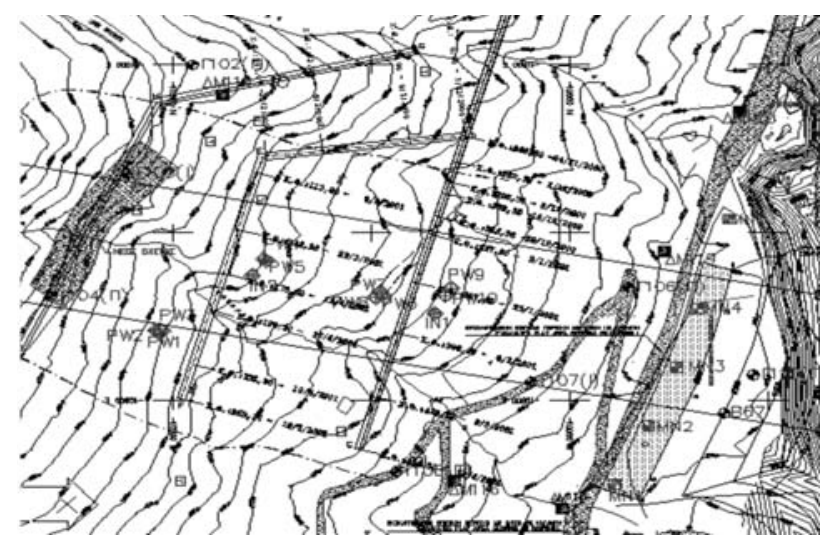

Fig. 12: Drainage tunnels and piezometers located in the area of the Road Landslide.

The stabilization works succeeded in reducing the overall movements to values between the limits of the instrumental measuring fault. Station K1 is located near by the group of piezometers П112-115, while station K2 is located nearby the group of piezometers П109-111.

\section{The landslide of the Agios Demetrios- Arahova Country Road}

The landslide occurred at the Agios Demetrios - Arahova Country Road during the construction of the Evinos reservoir project (1993). The stabilization interventions included the construction of toe berms, drainage tunnels, and surface runoff collection works. The behaviour of the stabilization interventions are monitored by in-situ measurements in a) piezometers, b) inclinometric-settlement columns, c) surface monumental stations, d) devices measuring the flow in the outlet of drainage tunnels. In fig. 12, the stabilization interventions are depicted together with the piezometers and surface monumental stations (Dounias et al., 2006). 


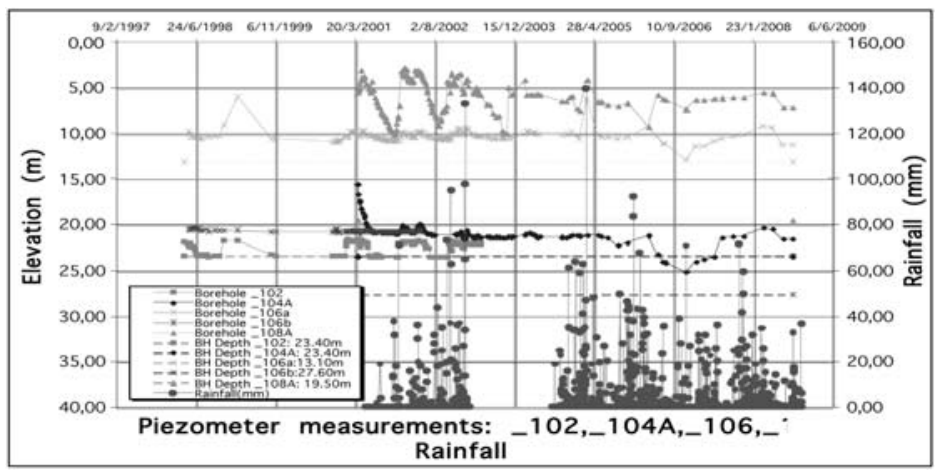

Fig. 13: Piezometric Measurements of Group $\Gamma 102, \Gamma 104 \mathrm{~A}, \Gamma 108 \mathrm{~A}$ and $\Gamma 106 \mathrm{a} \& \mathrm{~b}$.

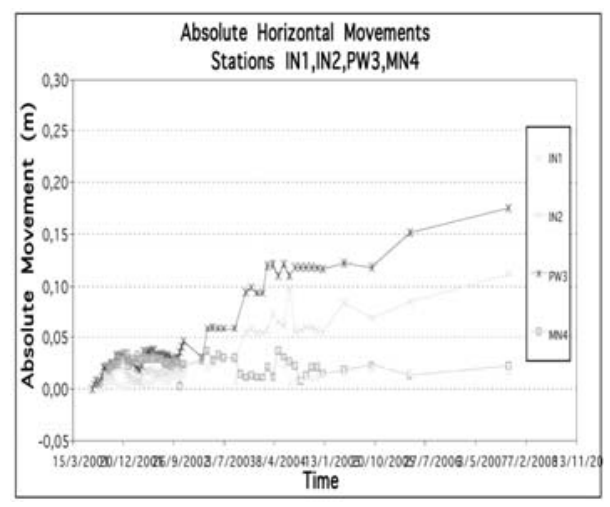

Fig. 14: Measurement of horizontal displacements in the area of Road Landslide.

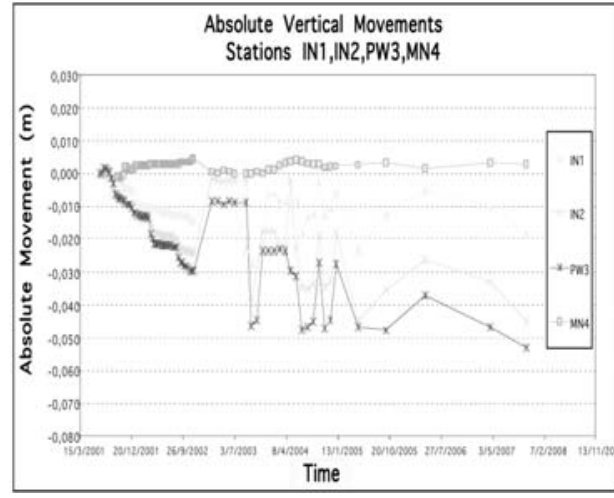

Fig. 15: Measurement of settlement in the area of Road Landslide.

\subsection{Piezometers}

Piezometers are installed in the area of Agios Demetrios-Arahova Country Road Landslide to record the fluctuation of piezometric level upstream and downstream the drainage tunnel. In fig. 13, the history of fluctuation of the piezometric levels of piezometers $\Gamma 102, \Gamma 104 \mathrm{~A}, \Gamma 108 \mathrm{~A}$ and $\Gamma 106 \mathrm{a} \& \mathrm{~b}$ is presented. In the same fig. 13 the rainfall level curve is also depicted. The piezometers that are located in depth levels greater than $15 \mathrm{~m}$ are affected by the drainage tunnel and show decreased peizometric levels in respect with piezometers placed in depth levels smaller than $15 \mathrm{~m}$. The measurements of piezometers placed deeply in the area of landslide are affected by the reservoir's water level rise.

\subsection{Settlement and horizontal movement}

In figs 14, 15 the horizontal displacement measurements together with the settlement measurements are shown for the area of the landslide. The horizontal displacements measured downstream the drainage tunnels appear to be reduced in MN4, IN1 stations compared to the horizontal displacements measured in stations located upstream the drainage tunnels (PW3, IN2 upper part of landslide). The settlement $(1,9 \mathrm{~cm})$ of the lower parts of landslide MN4,IN1 are smaller compared to the settlement recorded $(5.3 \mathrm{~cm})$ in stations PW3, IN2. 


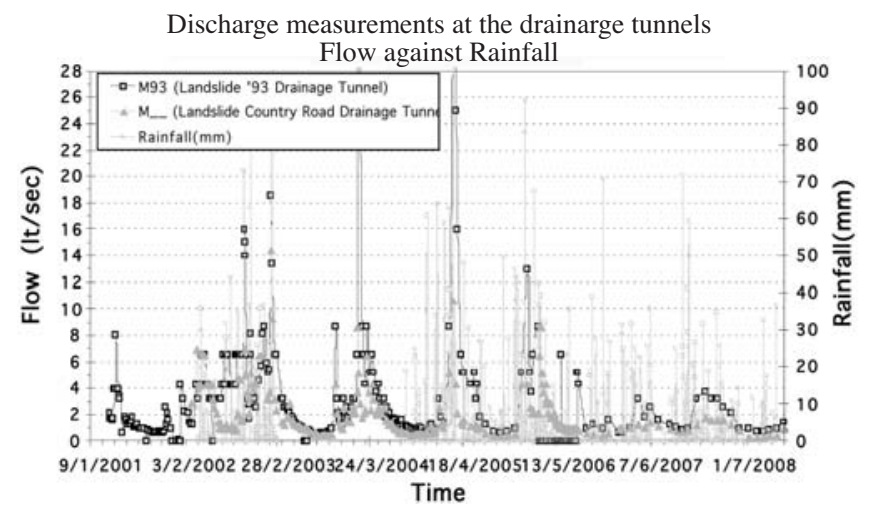

Fig. 16: Discharge measurements at the drainage tunnels in the areas of 1993 Landslide, and Country Road Landslide in relation to the rainfall.

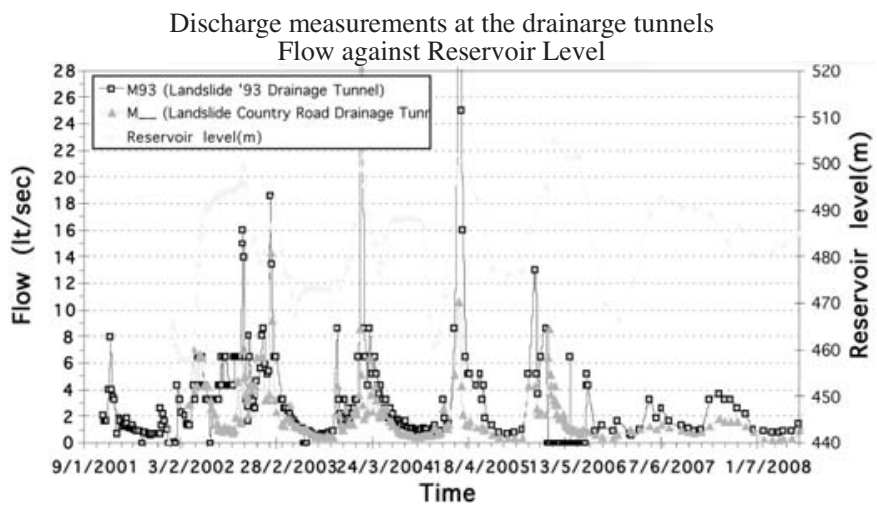

Fig. 17: Discharge measurements at the drainage tunnels in the areas of 1993 Landslide, and Country Road Landslide in relation to the reservoir level.

\section{Discharge through drainage tunnels}

In figs. 16, 17 the discharge measurements at the drainage tunnels of: a) Landslide of the left abutment ' 93 and b) Agios Demetrios-Arahova Country Road Landslide are depicted respectively. It is observed that the discharge at the outlets of these two drainage tunnels depends on the level of rainfall and exhibits immediate response. The discharge of the drainage tunnel within the landslide of the left abutment ' 93 depends on the reservoir level. It is shown that the discharge of the drainage tunnel within the landslide of the left abutment ' 93 is increased remarkably when the reservoir water level is above $+485 \mathrm{~m}$.

\section{Conclusions-Results}

- Upstream piezometers show piezometric level that follows the fluctuation of the reservoir's water level as expected.

- Downstream piezometers placed in the free draining material, present a constant low piezometric level through time, as expected. 
- Piezometers placed downstream the grout curtain show considerably low piezometric level which demonstrates the efficiency of the grout curtain.

- Surface monumental stations placed on the dam crest (S68-72 downstream), indicate "extension" of the dam's crest towards downstream, as well as a normal evolution of settlement.

- Drainage interventions are considered effective; as it is proved they have led to a considerable water level decrease in the deeper piezometers in both landslides.

- The horizontal displacements and settlement measured in surface monumental stations (K1, $\mathrm{K} 2$, K3) suggest that the landslide of the left abutment '93 is not active.

- The horizontal displacements and settlement measured downstream the drainage tunnels in the area of Agios Demetrios-Arahova Country Road Landslide appear to be reduced in comparison to the horizontal displacements and settlement measured in stations located upstream the drainage tunnels.

\section{Acknowledgments}

The authors would like to thank the personnel of the Department of Evinos Dam, Division of Raw Water Intake, Athens Water Supply and Sewage Company S.A for their help during fieldwork and their effort during field measurements. We thank the head of the Division of Raw Water Intake, Athens Water Supply and Sewage Company S.A, Mr. George Valavanis, for his persistent support in the preparation of this work.

\section{References}

Angelopoulos A., Soulis V., Malandraki V., 2007. Evaluation of instrumental results during the $4^{\text {th }}$ operational period of Evinos Dam, October 2006-September 2007, Internal Report Issue No 16, Division of Raw Water Intake, E.YD.A.P S.A, Greece, Athens .

Angelopoulos A., Soulis .V., Malandraki V., 2008. Evaluation of instrumental results during the $4^{\text {th }}$ operational period of Evinos Dam, October 2007-September 2008, Internal Report Issue No 17”, Division of Raw Water Intake, E.YD.A.P S.A, Greece, Athens .

Dounias G., Dede V., 2006. Stabilization of the '93 landslide at the Evinos reservoir with drainage galleries. Proceedings of the $5^{\text {th }}$ Greek Conference on Geotechical and Geoenvironmental Engineering, Greece, Xanthi.

Dounias G., Belokas G., Marinos P., 2006. The Landslide of the Agios Demetrios-Arahova Country Road, at the Evinos river Basin. Proceedings of the $5^{\text {th }}$ Greek Conference on Geotechical and Geoenvironmental Engineering, Greece, Xanthi.

Dounias G., 2006.The behaviour of clay core of the Evinos dam. Proceedings of the $5^{\text {th }}$ Greek Conference on Geotechical and Geoenvironmental Engineering, Greece, Xanthi.

Dounias, G. \& Papageorgiou, E., 2001, "Stresses and Strains in the Evinos dam, Greece", $X V^{\text {th }}$ International Conference on Soil Mechanichs \& Geotechnical Engineering. Istanbul, Vol. 1, pp. 401-404. 